\title{
Using Fruit-bearing Explants for Physiological Experiments
}

\author{
Guglielmo Costa, Rita Biasi, and Giannina Vizzotto \\ Department of Produzione Vegetale and Tecnologie Agrarie, University of Udine, 33100 Udine, Italy
}

George C. Martin

Department of Pomology, University of California, Davis, CA 95616-8683

\begin{abstract}
Additional index words. growth retardant, daminozide, paclobutrazol, sucrose, Prunus persica, nectarine, Prunus domestica, prune, Olea europaea, olive

Abstract. One- and three-node nectarine explants were compared with intact potted units of similar dimension. The explants and intact plants performed similarly as judged by rate of leaf photosynthesis, leaf and fruit respiration, and changes in fresh and dry weights. Water loss and transpiration were less in explants than intact plants after $24 \mathrm{~h}$. Explants with fruit of nectarine, olive, and prune were used to evaluate uptake and distribution of ${ }^{14} \mathrm{C}$-labeled paclobutrazol (PBZ), daminozide, and sucrose in plant parts. These comparisons reveal that the explant system is useful for primary testing of hypotheses, screening of chemicals, and evaluating species response for later testing of selected parameters in the field. Three-node explants containing fruit are reliable for experiments lasting up to 4 days. Chemical names used: succinic acid 2,2 dimethylhydrazide [daminozide (SADH)]; $\beta$-[(4-chlorophenyl)methyl]- $\alpha-(1,1$-dimethylethyl)-1H-1,2,4-triazole-1ethanol [paclobutrazol (PBZ)].
\end{abstract}

Physiological experiments with perennial plants in the field are made difficult by variable climatic conditions and orchard practices. Partial climate control is possible in the laboratory, but mature bearing trees cannot be accommodated in such a setting. A laboratory model system is needed using excised plant parts that will resemble plant metabolism when attached to a tree in the field. Such a model system affords primary testing of hypotheses concerning physiological response to horticultural or chemical treatment. An excised plant model system, as compared to large orchard trees, would be useful and less expensive in studying the complex interaction and multifactorial controls necessary for difficult interpretations (Zucconi and Bukovac, 1989).

Greenhouse containerized seedlings or grafted fruit trees grown on solid substrates or liquid media are useful for different applications of unlabelled or labelled chemicals and for checking their mobility and stability (Intrieri and Ryugo, 1974; Sterret, 1985; Richardson and Quinlan, 1986; Early and Martin, 1988a,1988b). The presence of fruit adds further complexity to the model plant; still, small, potted, bearing apple trees have been used to evaluate growth substance movement and activity (Biasi, 1990; Samaraweera and Hill-Cottingham, 1980). The purpose of our work was to 1) achieve a high level of simplicity and reliability using a fruiting explant model system to carry out short-term physiological studies; 2) verify the reliability and usefulness of the excised model plant system using ${ }^{14} \mathrm{C}$ forms of daminozide and paclobutrazol (PBZ) and 3) compare daminozide and PBZ transport and accumulation with that of ${ }^{14} \mathrm{C}$-labeled sucrose, a compound distributed all over the plant. The hypothesis we tested was that the fruiting excised model plant system could be used as a primary screening test to determine the ultimate accumulation and distribution of candidate chemicals to be tested later in the field.

Received for publication 7 June 1993. Accepted for publication 9 Sept. 1993. Research supported by CNR Bilateral Project Italy-USA. The cost of publishing this paper was defrayed in part by the payment of page charges. Under postal regulations, this paper therefore must be hereby marked advertisement solely to indicate this fact.

\section{Materials and Methods}

Physiological parameters. Excised nectarine shoots ('Spring Red') were chosen when average fruit diameter was 25 to $30 \mathrm{~mm}$. One-year-old shoots cut from adult trees were used to test two models: 1) a one-node model with one leaf and one fruit and 2) a three-node model with one leaf and one fruit per node. Representative, similar one-node units were also tagged on potted adult nectarine trees to compare results using the excised model. Excised model plants were kept in beakers containing $10 \mathrm{ml}$ water. Evaporation was prevented by wrapping the stem with a plastic film and covering the top of the beaker. Both excised and intact model plants were kept in the laboratory at $45 \%$ relative humidity and 23 to $24 \mathrm{C}$. Experiments were conducted with four replicates per treatment and repeated twice when physiological measurements were made.

Total water use, leaf $\mathrm{C}$ assimilation, transpiration, and respiration of leaves and fruits were measured to evaluate the performance and longevity of each system. Total water use was determined by measuring the water volume needed to replace the water used each day. Carbon dioxide assimilation (A) and transpiration were measured with a portable gas-exchange system (model LCA1; Analytical Development Co., Hoddesdon, U.K.). The measurements were carried out on both excised and intact models. For one-node model plants, the gas exchange was measured at 0 , 2, 6, 24, and $48 \mathrm{~h}$ after excision. For three-node model plants, measurements were taken at $0,1,2,4$, and 7 days after excision. Each time an excised model was tested for the above parameters, the one-node models on intact plants were tested. Explants were exposed to stepwise increases in photosynthetic photon flux density (PPFD) from 0 to $900 \mu \mathrm{mol} \cdot \mathrm{m}^{-2} \cdot \mathrm{s}^{-1}$. Respiration rates of leaves and fruits of the model plant were measured at 0,1 , and 2 days for the one-node model and $0,1,2,4$, and 7 days for the three-node and field models by using the polarographic $\mathrm{O}_{2}$ electrode (model 5300; YSI, Yellow Spring, Ohio) technique (Mottley, 1985). For this measurement, $100 \mathrm{mg}$ leaf or fruit mesocarp was isolated and maintained in ice immediately after cutting. The sample was minced with a razor blade and was incubated in $0.5 \mathrm{~m}$ phosphate 
buffer for $3 \mathrm{~min}$ at room temperature. After equilibration, $\mathrm{O}_{2}$ consumption was monitored for $5 \mathrm{~min}$ and expressed as $\mu \mathrm{mol} \mathrm{O}_{2} /$ $\mathrm{g}$ fresh weight persec. Two or three runs were carried out for each sample. To estimate the tissue respiration rate of intact models, nectarine shoots were taken from potted trees, and leaf and fruit respiration was measured immediately after excision. The fresh and dry weights of stems, leaves, and fruit for each model plant were determined at the end of the experiment.

Chemical distribution. Experiments were carried out using excised shoots of 'Stark Red Gold' nectarine, 'Manzanillo' olive, and 'French' prune. Explants were formed by excising shoots with one to three nodes and at least one leaf and one fruit per node. 'Stark Red Gold' nectarine shoots were taken at two different times-30 and 42 days after full bloom (AFB), corresponding to 11 and 23 $\mathrm{mm}$ in fruit diameter. 'Manzanillo' olive shoots were excised 42 days AFB and 'French' prune shoots were excised 20 days before harvest.

Compounds used and plant tissue extraction. The following compounds were used: ${ }^{14} \mathrm{C}$-labeled PBZ $\left(0.044 \mathrm{Ci} \cdot \mathrm{mmol}^{-1}\right.$ specific activity, 92.7\% purity, molecular weight (Mw) 293.6), ${ }^{14} \mathrm{C}$-labeled daminozide $\left(0.0251 \mathrm{Ci} \cdot \mathrm{mmol}^{-1}\right.$ specific acitivity, $99 \%$ purity, $\mathrm{Mw}$ $160)$, and ${ }^{14} \mathrm{C}$-labeled sucrose $\left(0.56 \mathrm{Ci} \cdot \mathrm{mmol}^{-1}\right.$ specific activity, 99\% purity, Mw 360). Plant tissues treated with ${ }^{14} \mathrm{C}$-labeled PBZ were extracted with the procedure used in previous studies (Early and Martin, 1988a,1988b), while those treated with ${ }^{14} \mathrm{C}$-labeled daminozide were homogenized and extracted in $80 \%$ methanol overnight and centrifuged. The supernatant was collected and dried down to the water fraction and adjusted to $\mathrm{pH} 3$ with $1 \mathrm{~N} \mathrm{HCl}$. The supernatant was then partitioned against ethyl acetate, and water fractions were saved, dried down, solubilized in high performance liquid chromatography (HPLC) solvent system $(90.05 \mathrm{M}$ $\mathrm{Na} \mathrm{H}_{2} \mathrm{PO}_{4}$ water : 1 methanol), and injected into an HPLC (LDC, Milton Roy HPLC, Riviera Beach, Fla.) under the following conditions: $10 \times 150 \mathrm{~mm}$ stainless steel, ODS 18 semi-preparative column; $90 \% 0.05 \mathrm{M} \mathrm{NaH}_{2} \mathrm{PO}_{4}$ water : $10 \%$ methanol isocratic solvent system; $2 \mathrm{ml} \cdot \mathrm{min}^{-1}$ flow rate and an ultraviolet detector wavelength of $220 \mathrm{~nm}$. Based on these conditions, daminozide has a retention time of $\approx 7 \mathrm{~min}$. To determine ${ }^{14} \mathrm{C}$-labeled daminozide breakdown products, 1 -min fractions were collected and radioactivity was checked.

Time of uptake. ${ }^{14}$ Carbon-labeled PBZ at $0.06 \mathrm{Ci}$ was applied to 'Manzanillo' olive excised shoots via the stem placed in 1-ml solutions in vials and left for 8,16 , and $24 \mathrm{~h}$. After the established uptake time, shoots were divided into stem, leaf, fruit, and peduncle. The treated part was rinsed with water and methanol, homogenized, and extracted in $80 \%$ methanol for $24 \mathrm{~h}$. After centrifugation, the supernatant was dried down, the residue was redissolved in a known amount of methanol, and an aliquot was taken to determine ${ }^{14} \mathrm{C}$ distribution in plant parts. The radioactivity in the beaker was also determined.

Species response. ${ }^{14}$ Carbon-labeled $\mathrm{PBZ}$ at $0.06 \mathrm{Ci}$ was applied to prune, olive, and nectarine excised shoots with the stem end placed in 1-ml solutions in beakers and left for $24 \mathrm{~h}$. The solution volume was replenished as needed. Subsequently, handling procedures for sampling, extraction, and counting conditions were as listed above.

Compounds tested and application methods. ${ }^{14}$ Carbon-labeled PBZ and ${ }^{14} \mathrm{C}$-labeled daminozide at $0.06 \mathrm{Ci}$ and ${ }^{14} \mathrm{C}$-labeled sucrose at $0.11 \mathrm{Ci}$ were applied to 'Stark Red Gold' nectarine onenode excised shoots. Compounds were applied either directly to the fruit surface, the leaf surface, or the cut stem in the vial as in the two previous experiments. Uptake was allowed for $24 \mathrm{~h}$.

Breakdown. ${ }^{14}$ Carbon-labeled PBZ and ${ }^{14} \mathrm{C}$-labeled daminozide at $0.06 \mathrm{Ci}$ were applied to 'Stark Red Gold' nectarine at the cut stem in the vial and uptake was allowed for 5 days. Extraction of plant tissue and identification procedures for ${ }^{14} \mathrm{C}$-labeled metabolites were as listed above.

\section{Results}

Water use. Under laboratory conditions, one- and three-node models used the most water during the $24 \mathrm{~h}$ after excision (Fig. 1), and the three-node model used more water than the one-node model. Both models showed a marked decrease in water use from 1 to 4 days. The one-node model here and in subsequent comparisons was not used beyond 2 days because of deteriorating leaf appearance.

Fresh and dry weight. At the end of the experiments, i.e., 2 days after the explant for the one-node model and 7 days for the threenode model, no significant differences were found among leaves or fruit fresh weight : dry weight ratios when compared to intact plants. Less water loss occurred from stems of the intact plants and one-node model than from the three-node model, resulting in fresh weight : dry weight ratios of $29.3,35.8$, and $37.4 \mathrm{mg} \cdot \mathrm{g}^{-1}$, respectively.

Respiration. For the first 2 days after taking the explant, leaf and fruit respiration of the one-node model were similar to the values measured in the intact model (Table 1). Values for the three-node model varied slightly through day 4 but declined precipitiously by day 7. Respiration in the intact model remained steady for leaf or fruit at each comparison period.

Gas exchange. One-node models responded to increasing light intensity (Fig. 2A). Positive A values were measured at $\approx 100$ PPFD for the intact plants and for the excised model $2 \mathrm{~h}$ after the explant was made, and at $\approx 200$ PPFD for subsequent measurements. The highest value for $A$ was found for the intact plants and excised model plants immediately after the explant was made, while it decreased over $48 \mathrm{~h}$ of model aging (Fig. 2A). The threenode model also responded to increased light intensity (Fig. 2B). Positive A values were measured for intact plants and excised plants at $0,1,2$, and 4 days after the explant was made at $\approx 100$ PPFD, whereas 7 days later $\approx 400$ PPFD was required for the positive value. As light increased, similar values for PPFD were obtained for the intact plant and 1- and 2-day-old model plants. By 4 days, the model plants showed a reduction in the A values starting from 200 PPFD, with the lowest values in the experiment occur-

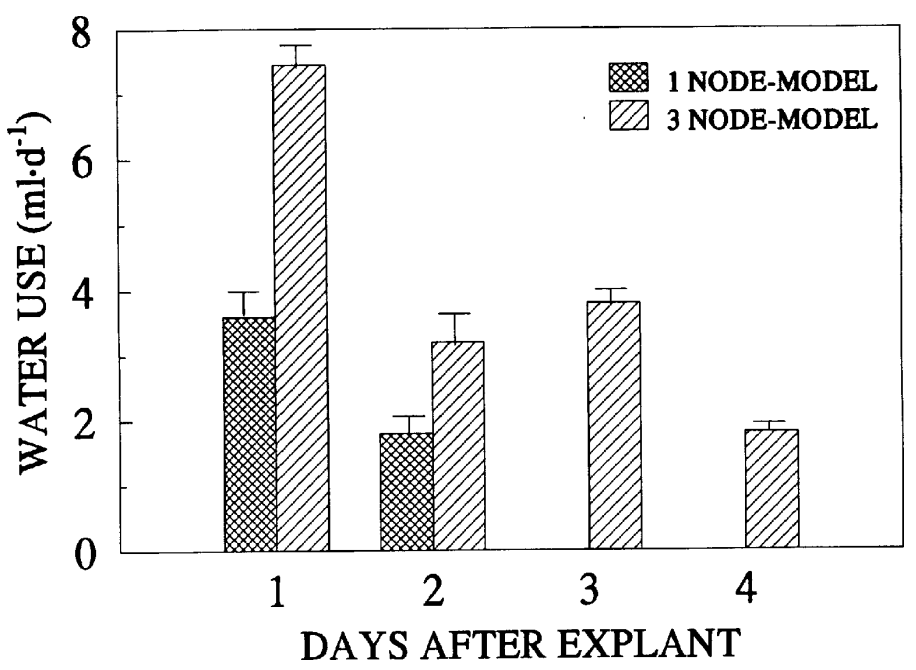

Fig. 1. Total water consumption of model plants after excision. Average water loss by evaporation was $0.1 \mathrm{ml} \cdot \mathrm{day}^{-1}$. Bars indicate SE. 
Table 1. Oxygen consumption of nectarine model and intact plants $\left(\mu \mathrm{mol} \mathrm{O} \mathrm{O}_{2} / \mathrm{g}\right.$ fresh weight per $\left.\mathrm{h}\right){ }^{\mathrm{z}}$

\begin{tabular}{|c|c|c|c|c|c|c|}
\hline \multirow{2}{*}{$\begin{array}{l}\text { Days } \\
\text { from } \\
\text { explant }\end{array}$} & \multicolumn{2}{|c|}{ One-node model } & \multicolumn{2}{|c|}{ Three-node model } & \multicolumn{2}{|c|}{ Intact plant } \\
\hline & Leaf & Fruit & Leaf & Fruit & Leaf & Fruit \\
\hline 0 & $18.5 \pm 1.7$ & $10.7 \pm 0.9$ & $18.3 \pm 0.8$ & $12.5 \pm 1.5$ & $19.0 \pm 1.3$ & $11.6 \pm 1.7$ \\
\hline 1 & $15.5 \pm 1.3$ & $10.3 \pm 0.2$ & $16.3 \pm 0.4$ & $12.3 \pm 0.1$ & $18.3 \pm 0.6$ & $12.1 \pm 0.9$ \\
\hline 2 & $19.6 \pm 4.2$ & $14.2 \pm 2.4$ & $14.2 \pm 3.5$ & $9.4 \pm 0.1$ & $19.0 \pm 1.2$ & $11.4 \pm 1.5$ \\
\hline 4 & --- & --- & $16.2 \pm 1.2$ & $10.0 \pm 1.4$ & $19.5 \pm 2.1$ & $10.9 \pm 1.1$ \\
\hline 7 & --- & --- & $4.2 \pm 1.0$ & --- & $19.5 \pm 1.9$ & $11.1 \pm 1.2$ \\
\hline
\end{tabular}

${ }^{\mathrm{z}}$ Means with SE.
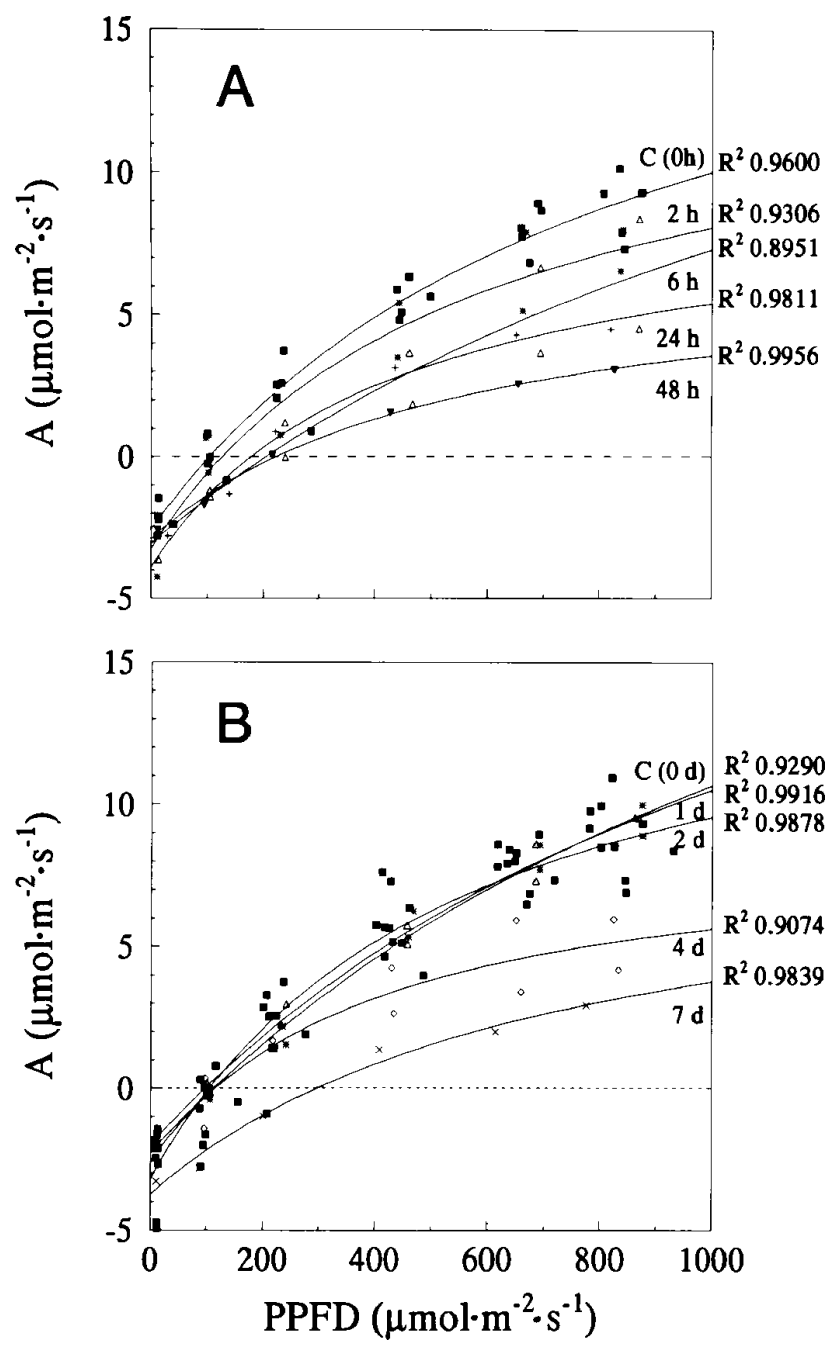

Fig. 2. Relationship between assimilation rate and photosynthetic photon flux density (PPFD) of the intact model shown with a " $\mathrm{C}$ " on the graphs and the onenode model plants (A) and intact and three-node model plants (B) during timecourse measurement. Intact model and 0 -h values for one- and three-node models were similar and only one curve is presented. ring at 7 days (Fig. 2B). Transpiration rate values show the onenode model losing more water than the intact plant $2 \mathrm{~h}$ after excision. Thereafter, transpiration was less than in the intact plant (Table 2). In the three-node model, the transpiration values were higher than the intact plant 1 day after the explant was made. Thereafter, the transpiration rate was lower than in the intact plant (Table 2).

Time of uptake. The distribution of ${ }^{14} \mathrm{C}$-labeled PBZ over an increasing period of uptake time in excised olive shoots led to the greatest accumulation in the stem and leaf (Table 3). After $8 \mathrm{~h}$, although total radioactivity increased, there was little change in the distribution of recovered radioactivity among plant parts analyzed. The stem and leaf contained $97.1 \%$ of the recovered radioactivity at $8 \mathrm{~h}$ and $96.0 \%$ by $24 \mathrm{~h}$. Very little radioactivity was found in the fruit at $8 \mathrm{~h}$, and by $24 \mathrm{~h}$ only $1.3 \%$ was recovered from olive fruit.

Species response. Recovered radioactivity for ${ }^{14} \mathrm{C}$-labeled PBZ treatment ranged from the highest content in the stem to the lowest in the fruit in all three species (Table 4). From $90 \%$ to $98 \%$ of the recovered radioactivity was found in the combined stem and leaf in all three species with radioactivity in fruit ranging from $0.9 \%$ to $3.4 \%$. 'French' prune had the highest percentage of radioactivity in the leaf and lowest in the fruit, whereas 'Stark Red Gold' nectarine had the lowest percentage of radioactivity in the leaf and highest in the fruit.

Compounds tested and application method. The two ${ }^{14} \mathrm{C}-\mathrm{la}-$ beled growth retardants and ${ }^{14} \mathrm{C}$-labeled sucrose showed different distribution patterns in nectarine (Table 5). When applied to stems via the solution in the vials, the radioactivity was observed in all plant parts. When applied to leaves or fruit, the uptake and distribution of the ${ }^{14} \mathrm{C}$ compounds were restricted. When applied to fruit, greater distribution of radioactivity was found from ${ }^{14} \mathrm{C}$ labeled daminozide treatment than from ${ }^{14} \mathrm{C}$-labeled PBZ. When applied to leaf or stem, greater distribution of radioactivity was found from ${ }^{14} \mathrm{C}$-labeled PBZ than from ${ }^{14} \mathrm{C}$-labeled daminozide application (Table 5).

In these comparisons, the applied radioactivity was most prominent at the place of application. ${ }^{14}$ Carbon-labeled daminozide penetrated into treated fruit to a greater extent than ${ }^{14} \mathrm{C}$-labeled PBZ, as judged by radioactivity in fruit and rinse comparisons. In all comparisons, less ${ }^{14} \mathrm{C}$-labeled PBZ was found in fruits than was

Table 2. Transpiration rate $\left(\mathrm{mmol} \mathrm{H}_{2} \mathrm{O} / \mathrm{m}^{2}\right.$ per sec) of one- and three-node models and intact plants. ${ }^{\mathrm{Z}}$

\begin{tabular}{|c|c|c|c|c|c|}
\hline $\begin{array}{l}\text { Time } \\
\text { (h) }\end{array}$ & $\begin{array}{l}\text { One-node } \\
\text { model }\end{array}$ & Intact plant & $\begin{array}{l}\text { Time } \\
\text { (days) }\end{array}$ & $\begin{array}{c}\text { Three-node } \\
\text { model }\end{array}$ & Intact plant \\
\hline 0 & $7.02 \pm 1.0$ & $7.05 \pm 2.3$ & 0 & $5.85 \pm 2.2$ & $7.93 \pm 1.3$ \\
\hline 2 & $8.23 \pm 1.11$ & $6.40 \pm 1.4$ & 1 & $8.01 \pm 0.56$ & $6.70 \pm 2.4$ \\
\hline 6 & $5.15 \pm 1.17$ & $6.75 \pm 0.6$ & 2 & $5.19 \pm 0.30$ & $6.59 \pm 1.4$ \\
\hline 24 & $3.63 \pm 1.20$ & $6.70 \pm 2.4$ & 4 & $4.23 \pm 0.03$ & $7.48 \pm 0.7$ \\
\hline 48 & $4.21 \pm 0.13$ & $6.59 \pm 1.4$ & 7 & $5.77 \pm 0.31$ & $5.95 \pm 0.8$ \\
\hline
\end{tabular}

${ }^{\mathrm{z} M e a n s}$ with SE. 
Table 3. Distribution of the radioactivity in a one-node excised shoot of olive as related to different periods of ${ }^{14} \mathrm{C}$-labeled paclobutrazol uptake when applied to stems. ${ }^{\mathrm{Z}}$

\begin{tabular}{|c|c|c|c|c|c|c|}
\hline \multirow[b]{3}{*}{ Plant part } & \multicolumn{6}{|c|}{ Time of uptake (h) } \\
\hline & \multicolumn{2}{|c|}{8} & \multicolumn{2}{|c|}{16} & \multicolumn{2}{|c|}{24} \\
\hline & $\mathrm{nCi}$ & $(\%)^{y}$ & $\mathrm{nCi}$ & $(\%)$ & $\mathrm{nCi}$ & $(\%)$ \\
\hline stem & 33.44 & 74.6 & 31.73 & 70.8 & 32.04 & $\overline{71.7}$ \\
\hline leaf & 9.65 & 21.6 & 12.11 & 27.0 & 11.04 & 24.7 \\
\hline fruit & 0.27 & 0.6 & 0.27 & 0.6 & 0.58 & 1.3 \\
\hline peduncle & 0.22 & 0.5 & 0.22 & 0.5 & 0.36 & 0.8 \\
\hline vial & 1.21 & 2.7 & 0.47 & 1.1 & 0.67 & 1.5 \\
\hline
\end{tabular}

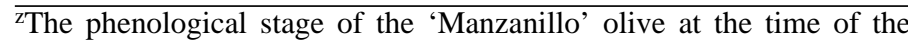
application of the ${ }^{14} \mathrm{C}$-labeled paclobutrazol was 6 weeks after full bloom. yOf the radioactivity recovered, the percent found in each plant part. Of the total radioactivity applied, the average percent recovered was $74.4 \%$.

Table 4. Distribution of the recovered radioactivity in one-node excised shoots of prune, olive, and nectarine after $24 \mathrm{~h}$ of ${ }^{14} \mathrm{C}$-labeled paclobutrazol stem application ${ }^{\mathrm{Z}}$.

\begin{tabular}{|c|c|c|c|c|c|c|}
\hline \multirow[b]{2}{*}{ Plant part } & \multicolumn{2}{|c|}{ 'French' prune } & \multicolumn{2}{|c|}{ 'Manzanillo' olive } & \multicolumn{2}{|c|}{$\begin{array}{c}\text { 'Stark Red Gold } \\
\text { nectarine }\end{array}$} \\
\hline & $\mathrm{nCi}$ & $(\%)^{y}$ & $\mathrm{nCi}$ & $(\%)$ & $\mathrm{nCi}$ & $(\%)$ \\
\hline Stem & 25.89 & 57.6 & 32.04 & 71.7 & 38.55 & 85.6 \\
\hline Leaf & 17.68 & 39.4 & 11.04 & 24.6 & 4.93 & 11.0 \\
\hline Fruit & 0.40 & 0.9 & 0.58 & 1.3 & 1.52 & 3.4 \\
\hline Peduncle & 0.85 & 1.9 & 0.36 & 0.8 & --- & --- \\
\hline Vial & 0.09 & 0.2 & 0.67 & 1.5 & --- & --- \\
\hline
\end{tabular}

$\overline{\text { ZPhenological stages of the fruit at the time of application: 'Stark Red }}$ Gold' nectarine, 30-days after full bloom (AFB) when the fruit diameter was $11 \mathrm{~mm}$; 'Manzanillo' olive, 6 weeks AFB, which is 7 months before physiological maturity; 'French' prune, 20 days before harvest.

${ }^{\mathrm{y}} \mathrm{Of}$ the radioactivity recovered, the percent found in each plant part. Of the total radioactivity applied, the average percent recovered was $76.7 \%$.

${ }^{14} \mathrm{C}$-labeled sucrose or ${ }^{14} \mathrm{C}$-labeled daminozide.

Breakdown. Breakdown compounds from ${ }^{14} \mathrm{C}$-labeled PBZ application were found at 8 and $9 \mathrm{~min}$ in nectarine fruit, with the major peak shown at the same retention time as PBZ (Fig. 3A). In contrast, no recovered radioactive breakdown compounds from ${ }^{14} \mathrm{C}$-daminozide application were found in the plant parts tested (Fig. 3B).

\section{Discussion}

The model systems examined in this study provide short-term vitality for physiological experiments. As judged by $\mathrm{C}$ assimilation, respiration, and fresh or dry weights, the one- and three-node models would be reliable for 2 and 4 days, respectively. After that, explants began to wilt and measured physiological parameters declined. Water use and transpiration in both models rapidly declined after $24 \mathrm{~h}$. In part, this may be offset by using 8hydroxyquinoline citrate. This additive in the uptake solution lowers bacterial populations that can occlude xylar pathways that decrease water uptake (Glandon and Staby, 1973).

Model plant convenience was revealed in the uptake and distribution of ${ }^{14} \mathrm{C}$ compounds. This feature makes the explant system useful for short-term screening of candidate chemicals or treatments to be used later on field-grown trees. The tested responses of daminozide and PBZ in the explants compare well with published research on intact plants in the orchard or greenhouse
Table 5. Distribution of the radioactivity in one node excised shoots of nectarine as related to three ${ }^{14} \mathrm{C}$-labeled compounds [paclobutrazol, daminozide, sucrose] and application (leaf, fruit, vial) ${ }^{\mathrm{Z}}$.

\begin{tabular}{|c|c|c|c|c|c|c|}
\hline \multirow[b]{2}{*}{ Plant party ${ }^{y}$} & \multicolumn{2}{|c|}{ Sucrose } & \multicolumn{2}{|c|}{ Daminozide } & \multicolumn{2}{|c|}{ PBZ } \\
\hline & $\mathrm{nCi}$ & $(\%)^{x}$ & $\mathrm{nCi}$ & $(\%)$ & $\mathrm{nCi}$ & $(\%)$ \\
\hline Stem & 3.54 & 5.4 & 0.11 & 0.3 & 0.04 & 0.1 \\
\hline [Fruit] & 11.69 & 17.8 & 12.36 & 32.6 & 3.81 & 8.5 \\
\hline Leaf & 0.13 & 0.2 & 0.11 & 0.3 & 0.04 & 0.1 \\
\hline Rinse & 50.17 & 76.5 & 25.22 & 66.5 & 40.93 & 91.2 \\
\hline Vial & 0.06 & 0.1 & 0.11 & 0.3 & 0.04 & 0.1 \\
\hline Stem & 0.39 & 0.6 & 0.19 & 0.5 & 0.31 & 0.7 \\
\hline Fruit & 0.33 & 0.5 & 0.72 & 1.9 & 0.13 & 0.3 \\
\hline [Leaf] & 4.14 & 6.3 & 0.91 & 2.4 & 4.57 & 10.2 \\
\hline Rinse & 60.74 & 92.5 & 35.91 & 94.7 & 39.72 & 88.5 \\
\hline Vial & 0.06 & 0.1 & 0.19 & 0.5 & 0.1 & 0.3 \\
\hline Stem & 27.97 & 41.8 & 7.42 & 17.8 & 34.06 & 75.9 \\
\hline Fruit & 17.47 & 26.1 & 14.44 & 34.6 & 1.52 & 3.4 \\
\hline Leaf & 6.69 & 10.0 & 16.80 & 40.3 & 4.17 & 9.3 \\
\hline Rinse & 0.0 & 0.0 & 0.0 & 0.0 & 0.0 & 0.0 \\
\hline [Vial] & 14.84 & 22.1 & 3.03 & 7.3 & 0.51 & 11.4 \\
\hline
\end{tabular}

'The phenological stage of the 'Stark Red Gold' nectarine at the moment of the application of the ${ }^{14} \mathrm{C}$-labeled compounds was 62 days after full bloom when fruit diameter was $23 \mathrm{~mm}$.

yThe bracket indicates where the ${ }^{14} \mathrm{C}$-radioactive compound was applied. ${ }^{x}$ Of the radioactivity recovered, the percent found in each plant part. Of the total radioactivity applied, the average percent recovered was $59.7 \%$ for sucrose, $63.2 \%$ for daminozide, and $74.7 \%$ for PBZ.
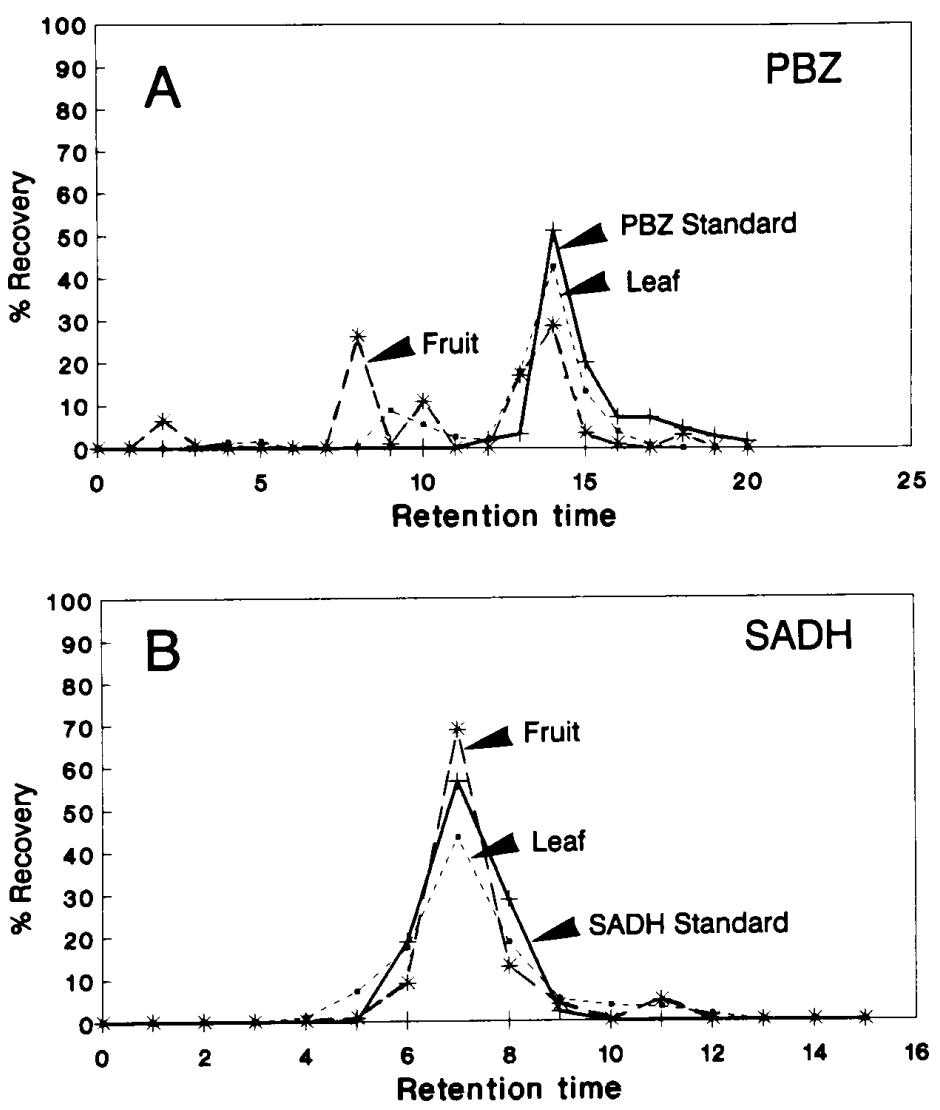

Fig. 3. Chromatogram of ${ }^{14} \mathrm{C}$-labeled paclobutrazol (PBZ) (A) and ${ }^{14} \mathrm{C}$-labeled daminozide (SADH) $(\mathbf{B})$ extracted from nectarine leaf and fruit tissues. 
(Early and Martin 1988a,1988b; Martin and Williams, 1966; Martin et al., 1964; Steffens et al., 1983). The uptake and distribution of ${ }^{14} \mathrm{C}$-labeled daminozide and ${ }^{14} \mathrm{C}$-labeled sucrose were similar, while both compounds behaved differently than ${ }^{14} \mathrm{C}$ labeled PBZ. When ${ }^{14} \mathrm{C}$-labeled PBZ was applied via the nectarine stem, only $3.4 \%$ of the recovered radioactivity was found in the fruit and up to $76 \%$ was found in the stem. In contrast, $>34 \%{ }^{14} \mathrm{C}$ labeled daminozide was recovered from fruit. The PBZ results obtained with excised model plant system agree with those previously reported with intact plants, confirming PBZ movement in the xylem (Early and Martin, 1988a) and reduced translocation to other parts of the plant when applied to the leaf (Xang et al., 1986) or even to the fruit.

Our results showed that daminozide and sucrose achieved greater overall distribution in the excised plants than PBZ. The daminozide results are consistent with previous findings on whole plant distribution (Martin and Williams, 1966; Undurraga and Ryugo, 1970). Further, after foliar sprays, presence of daminozide in fruits is high for both apples (Looney et al., 1972; Samaraweera and Hill-Cottingham, 1980) and cherries (Peisker and Sternkoff, 1976; Ryugo, 1966).

For all three compounds tested, stem treatment via solution in the vials was the most effective for uptake and allowed greater distribution of the ${ }^{14} \mathrm{C}$-labeled growth retardants and ${ }^{14} \mathrm{C}$-labeled sucrose. The preliminary observation on the breakdown of the two growth retardants showed that the excised model plant system may also be used for such investigations. We found PBZ breakdown in these short-term experiments similar to that reported by others with whole plants (Early and Martin, 1988b). We did not find daminozide breakdown in $24 \mathrm{~h}$, whereas other authors detected daminozide residues in fruit several weeks after treatment (Edgerton and Greenhalgh, 1967; Martin et al., 1964; Martin and Williams, 1966; Winter et al., 1983). In some investigations, further decomposition of daminozide in fruits was indicated after the fruit had reached full size (Samaraweera and Hill-Cottingham, 1980).

The explant system confirms previous results, demonstrating that, to minimize accumulation of compounds in the fruit and achieve the best results, PBZ and daminozide should be applied in different ways. PBZ is effective when applied to leaves or as a soildrench, whereas daminozide must be applied to foliage (Costa and Biasi, 1986; Curry, 1988; Martin et al., 1987; Quinlan, 1981). Thus, PBZ should be applied to roots, as less PBZ accumulated in fruit when applied via stem treatment than when applied to fruit surface. In addition, PBZ effectively controlled peach seedling vegetative growth when applied at doses as low as $3.4 \times 10^{-1} \mu \mathrm{g}$ (Early and Martin, 1988b).

A similar amount of recovered radioactivity after ${ }^{14} \mathrm{C}$-labeled daminozide treatment was found with both fruit or stem applications. With daminozide, the only practical way to reduce accumulation in fruit is to use the lowest chemical amount needed to obtain the desired effect or to apply the compound as a fall treatment after the fruits have been harvested, which reduces carryover effects on the next year's crop (Costa et al., 1975).

In conclusion, the explant system can be used as a primary, short-term duration screen for physiological questions to be later tested in the field after treatment number has been reduced. We offer three useful features of the explant system: 1) the use of labelled chemicals in the laboratory setting where contamination is more easily contained than in field plots, 2) rapid screening of hypotheses, and 3) opportunity for initial description of specific species and chemical response interactions.

\section{Literature Cited}

Biasi, R. 1990. Effects of polyamine-inhibitor spray on the initial phases of apple fruit growth. XXIII IHC (Abstr.) 2:4218.

Costa, G., N. Filiti, and G. Cristoferi. 1975. Effect of daminozide fall sprays on the fruit set and yield of pear. Riv. Ortoflorofrutt. Ital. 59:198-203.

Costa, G. and R. Biasi. 1986. Impiego di brachizzanti per il controllo vegetativo e produttivo del melo. Riv. Ortoflorofrutt. Ital. 70:125-134.

Curry, E.A. 1988. Chemical control of vegetative growth of deciduous fruit trees with paclobutrazol and RSW 0411. HortScience 23:470-473.

Early, J.D., Jr., and G.C. Martin. 1988a. Translocation and breakdown of ${ }^{14} \mathrm{C}$ labeled paclobutrazol in 'Nemaguard' peach seedling. HortScience 23:196-200.

Early, J.D., Jr., and G.C. Martin. 1988b. Sensitivity of peach seedling vegetative growth to paclobutrazol. HortScience 113:23-27.

Edgerton, L.J. and W.J. Greenhalgh. 1967. Absorption, translocation and accumulation of labeled $N$-dimethylamino-succinamic acid in apple tissues. Proc. Amer. Soc. Hort. Sci. 91:25-30.

Intrieri, C. and K. Ryugo. 1974. Uptake, transport and metabolism of (2chloroethyl)trimethylammonium chloride in seedlings of almond (Prunus amygdalus, Batsch). J. Amer. Soc. Hort. Sci. 99:349-352.

Glandon, R.J. and G.L. Staby. 1973. Opening of bud-cut chrysanthemums. HortScience 8:281.

Looney, N.E., K. Williams, and G.A. Wardle. 1972. Factors influencing the levels of succinic acid 2,2 dimethylhydrazide in apple fruits. J. Amer. Soc. Hort. Sci. 97:323-5.

Martin, G.C. and W.M. Williams. 1966. Breakdown products of $\mathrm{C}^{14}$ labeled $\mathrm{N}$ dimethyl amino succinamic acid (Alar) in the apple tree. Proc. Amer. Soc. Hort. Sci. 89:1-9.

Martin, G.C., W.M. Williams, and L.P. Batjer. 1964. Movement and fate of labeled $N$-dimethyl amino succinamic acid (B-Nine), a size controlling compound, in apple seedlings. Proc. Amer. Soc. Hort. Sci. 84:7-13.

Martin, G.C., F. Yoshikawa, and J. LaRue. 1987. Effect of soil applications of paclobutrazol on vegetative growth, pruning time, flowering yield and quality of 'Flavorcrest' peach. J. Amer. Soc. Hort. Sci. 112:315-319.

Mottley, J. 1985. Comparison of the tissue rates of photosynthesis and respiration in the leaves of different maize cultivars using the oxygen electrode. Cereal Res. Commun. 13:247-252.

Peisker, K. and G. Sternkoff. 1976. Investigations into the uptake, translocation and residue dynamics of the growth retardant B-9 (succinic acid dimethylhydrazide) with the 'Iltenburger Relomen Kirsche' cherry variety. Arch. fur Gartbenbau 24:327-33.

Quinlan, J.D. 1981. New chemical approaches to the control of fruit tree form and size. Acta Hort. 120:95-105.

Richardson, P.J. and J.D. Quinlan. 1986. Uptake and translocation of paclobutrazol by shoots of M26 apple rootstock. Plant Growth Regulat. 4:347-356.

Ryugo, K. 1966. Persistence and mobility of Alar (B-995) and its effect on anthocyanin metabolism in sweet cherries Prunus qvium. Proc. Amer. Soc. Hort. Sci. 88:160-166.

Samaraweera, M.K.S.A. and D.G. Hill-Cottingham. 1980. Uptake, distribution and persistence of ${ }^{14} \mathrm{C}$-labeled $\mathrm{N}$-dimethylamminosuccinamic acid in fruiting apple trees. J. Amer. Soc. Hort. Sci. 55:199-205.

Steffens, G.L., S.Y. Xang, C.L. Steffens, and T. Brennon. 1983. Influence of paclobutrazol (PP 333) on apple seedling growth and physiology. Proc. Plant Growth Regulat. Soc. Amer. 10:195-205.

Sterret, J.P. 1985. Paclobutrazol. a promising growth inhibitor for injection into woody plants. J. Amer. Soc. Hort. Sci. 110:4-8.

Undurraga, M.J. and K. Ryugo. 1970. The effect of Alar on permeability, a possible explanation for its mode of translocation. J. Amer. Soc. Hort. Sci. 95:348-354.

Winter, C., A. Craigmill and M. Stimman. 1983. NRAC Report and Alar. Environmental toxicology. UCD vol 9. 2:2-5.

Xang, S.Y., T. Sun, and M. Faust. 1986. Translocation of paclobutrazol, a gibberellin biosynthesis inhibitor, in apple seedlings. Plant Physiol. 82:11-14.

Zucconi, F. and M.J. Bukovac. 1989. Approaches to phytohormone studies on regulation of plant processes. A reassessment. Hort. Rev. 11:1-13. 